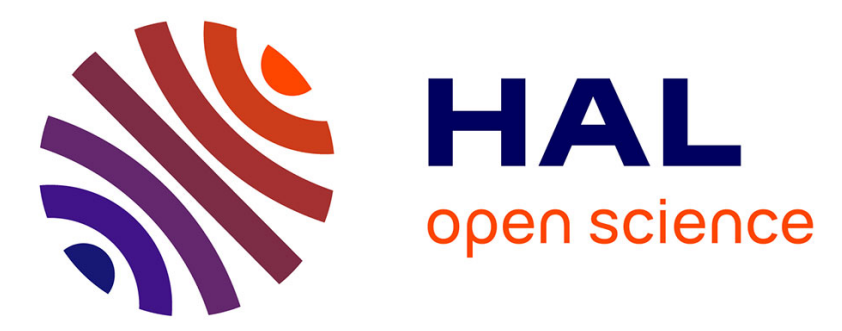

\title{
Type, density, and presentation of grafted adhesion peptides on polysaccharide-based hydrogels control preosteoblast behavior and differentiation.
}

Jing Jing, Audrey Fournier, Anna Szarpak-Jankowska, Marc R Block, Rachel Auzély-Velty

\section{To cite this version:}

Jing Jing, Audrey Fournier, Anna Szarpak-Jankowska, Marc R Block, Rachel Auzély-Velty. Type, density, and presentation of grafted adhesion peptides on polysaccharide-based hydrogels control preosteoblast behavior and differentiation.. Biomacromolecules, 2015, 16 (3), pp.715-22. inserm01135586

\section{HAL Id: inserm-01135586 https://www.hal.inserm.fr/inserm-01135586}

Submitted on 25 Mar 2015

HAL is a multi-disciplinary open access archive for the deposit and dissemination of scientific research documents, whether they are published or not. The documents may come from teaching and research institutions in France or abroad, or from public or private research centers.
L'archive ouverte pluridisciplinaire HAL, est destinée au dépôt et à la diffusion de documents scientifiques de niveau recherche, publiés ou non, émanant des établissements d'enseignement et de recherche français ou étrangers, des laboratoires publics ou privés. 


\section{Type, density, and presentation of grafted adhesion peptides on} polysaccharide based hydrogels control pre-osteoblast behavior and

\section{differentiation}

Jing Jing ${ }^{a}$, Audrey Fournier ${ }^{a}$, AnnaSzarpak-Jankowska ${ }^{a}$, Marc R. Block ${ }^{b}$ and Rachel AuzélyVelty $^{a *}$

${ }^{a}$ Univ. Grenoble Alpes; CERMAV, F-38000 Grenoble, France; CNRS, CERMAV, F-38000 Grenoble, France

${ }^{\mathrm{b}}$ Univ. Grenoble Alpes; Institut Albert Bonniot, CR INSERM U823; team 4; BP170, F-38042 Grenoblecedex 09, France

\section{*Corresponding author}

Tel: +33 4760376 71. E-mail: rachel.auzely@ cermav.cnrs.fr

\section{ABSTRACT:}

In this work, cell-responsive polysaccharide hydrogels were prepared by a simple procedure based on the sequential bioconjugation and crosslinking of the polysaccharide backbone with bioactive peptides and poly(ethylene glycol)-bis(thiol) (PEG-(SH) $)$, respectively. Using thiolene reactions, we successfully functionalized hyaluronic acid (HA) and carboxymethylcellulose (CMC) with short and long peptides (5-mer and 15-mer derivatives, respectively) derived from adhesive proteins of bone extracellular matrix. The resulting HA-peptide and CMC-peptide 
1 conjugates with varying degrees of substitution were then carefully characterized by ${ }^{1} \mathrm{H}$ NMR

2 spectroscopy to precisely control the peptide density into the hydrogels crosslinked with PEG-

$3(\mathrm{SH})_{2}$. Pre-osteoblast seeded on the hydrogels with controlled identical stiffness spread in a

4 manner that was strongly dependent on ligand density. Surprisingly, increasing the density of the

5 adhesive peptide anchors did not result in a plateau of initial cell spreading but rather in a bell-

6 shaped cell response which varies with the nature of both polysaccharide backbone and

7 functional peptide. Placing the cells under optimal conditions for cell/hydrogel interaction, we

8 showed that in HA hydrogels, the polysaccharide moiety is not solely a passive scaffold that

9 presents the active peptides but is an active player in cell microenvironment to control and sustain 10 cell activity.

12 Keywords: hyaluronic acid, hydrogel, thiol-ene, cell-adhesion, osteoblasts

\section{INTRODUCTION}

15 Bio-instructive, -specific, and -responsive hydrogels mimicking the extracellular matrix (ECM)

16 environment have emerged out of the traditional landscape of inert biomaterials. ${ }^{1-3}$ They are often

17 made of natural polysaccharides that act as scaffold for cellular guidance and wound healing

18 while they may also be subjected to biodegradation and can be replaced by bona fide extracellular

19 matrix over time. In addition, their biophysical properties such as compliance can be easily tuned

20 to match the physiological cellular environment and have been of broad use such as in vitro

21 culture and maintenance of stem cells, or direct stem cell specification. ${ }^{4-5}$ Indeed, changes in

22 tissue and organ stiffness are frequently symptoms of diseases such as cancer. ${ }^{6}$ 
1 Hyaluronic acid is a high molar mass $(6-7000 \mathrm{~kg} / \mathrm{mol})$ linear glycosaminoglycan found in soft

2 tissues such as connective, epithelial and neuronal tissues, and synovial fluid as well. It consists

3 of a repeating disaccharide unit made of $N$-acetyl-D-glucosamine and D-glucuronic acid residues.

$4 \quad{ }^{7-8}$ This polysaccharide can be obtained with a high degree of purity (pharmaceutical grade) on a

5 large scale by bacterial fermentation which makes it very attractive for designing soft materials in

6 the biomedical field. Various functional groups such as sulfate, (meth)acrylate, alkyl chains but

7 also host molecules, and peptides can be introduced along the polysaccharide backbone in order

8 to control gelation or compliance and trigger cell specific interactions with cell surface

9 receptors. ${ }^{9-12}$ Therefore this polysaccharide has been widely used to produce a variety of tailor

10 made hydrogels. ${ }^{11,13-14}$ Other hydrogels relying on polysaccharides that are not present in human

11 tissues (carboxymethylcellulose, chitosan, alginates...), may be chosen for their longer resistance

12 to in vivo environment while keeping their biocompatibility.

13 The cell surface receptors integrins are viewed as major players of cell adhesion to the

14 extracellular matrix and transmit signals to cells upon occupancy with extracellular ligands as

15 well as acting as mechano-transduction sensors. ${ }^{15}$ Their roles have been emphasized in many

16 biological processes such as development, immune response, migration, and hemostasis. ${ }^{16-19}$ In

17 addition, on mammalian cells, four major classes of HA cell receptors have been described:

$18 \mathrm{CD} 44$ standard or variants, ${ }^{20}$ their co-receptor RHAMM,${ }^{21}$ layilin, ${ }^{22}$ and ICAM-1 ${ }^{23}$. So far, little

19 is known about the role of HA receptors in cell signaling as well as their putativecrosstalk with

20 other well-established partners of cell/ECM interactions such as integrins, although recent reports

21 have described some interplay between HA and integrin substrate in controlling cell behavior. ${ }^{24}$

22 On the other hand, many cell types can attach and spread onto HA hydrogels in a stiffness-

23 dependent manner. This indicates that beside integrins, HA receptors may act as mechano-

24 sensors as well. ${ }^{25}$ However this adhesion is cell type dependent and is weaker than integrin 
1 mediated adhesion. This is in contrast to non-mammalian polysaccharide-based gels which are

2 generally resistant to cell-adhesion. Such hydrogel matrices are often used to provide a blank

3 canvas in which peptides containing consensus sequences recognized by integrins such as the

4 Arg-Gly-Asp (RGD) sequence are immobilized, thereby providing a defined chemical

5 environment to regulate cell functions. Naturally derived alginate is an example of such hydrogel

6 in which ligand density was found to be a critical regulator of adhesion, spreading, proliferation,

7 and differentiation of pre-osteoblasts. ${ }^{26}$ Yet, for properly probing cell responses to these soft

8 matrices, polysaccharide hydrogels with independently tunable stiffness and biochemical ligand

9 density must be carefully designed. ${ }^{5} \mathrm{We}$ have previously shown that ene-functional

10 polysaccharides esterified with pentenoic anhydride can be rapidly cross-linked with di-

11 functional thiols via thiol-ene photochemistry under physiological conditions. ${ }^{27}$ Cell-responsive

12 polysaccharide hydrogels were thus prepared by a simple procedure based on the sequential

13 bioconjugation and crosslinking of the polysaccharide backbone with a bioactive peptide and

14 poly(ethylene glycol)-bis(thiol), respectively. By varying the initial reactant stoichiometry as well

15 as the nature of the biomolecules, this strategy offers enormous possibilities in the design of

16 reproducible, highly tunable gels of which the cell-adhesive and mechanical properties are

17 independently controlled.

18 In this work, we used this procedure to investigate cell adhesion, spreading, and proliferation in

19 short term culture as well as differentiation in long term culture of pre-osteoblasts on hydrogels

20 depending on theirpolysaccharide component (hyaluronic acid vs carboxymethylcellulose) as

21 well as on peptide type and density.The peptides used are derived from adhesive proteins present

22 in the ECM of bone, namely fibronectin (Fn) and bone sialoprotein (bsp). They consist of

23 GRGDS (a fragment fromFn) ${ }^{28}$ and Ac-CGGNGEPRGDTYRAY-NH ${ }_{2}$ (a 15-mer derived from

24 bone sialoprotein, and here denoted as bsp-RGD) ${ }^{29}$. These two RGD peptides were selected 
1 because they have shown promise for use in orthopedic tissue engineering applications by

2 improving the adhesion and function of a number of osteoblastic cell lines. ${ }^{30-31}$ While several HA-

3 based hydrogels with tunable stiffness and RGD-ligand density have been reported in the

4 literature, ${ }^{32-36}$ the potential regulatory role of presentation of adhesion peptides in terms of

5 polysaccharide backbone, type and density on 2D cell culture has never been examined in detail.

6 Herein, we demonstrated ability to form HA-based gels that either permit or inhibit cell spreading

7 according to the ligand density at fixed stiffness. Moreover, by comparing cell responses to HA-

8 based gels with those to CMC-gels, at optimal peptide density allowing to support efficient

9 spreading of pre-osteoblasts, HA-peptide hydrogels versus CMC peptide hydrogels allowed a

10 better differentiation of pre-osteoblasts into osteoblasts (using increased mineralization

11 capabilities as a read-out). Therefore in addition to peptide-induced integrin signaling, the HA

12 backbone triggers an additional signal that was required for differentiation.

\section{MATERIALS AND METHODS}

15 Materials.Bacterial hyaluronic acid under the sodium salt form $\left(M_{w}=120 \mathrm{~kg} / \mathrm{mol}\right)$ was 16 purchased from HTL (Javené, France). The sample of carboxymethylcellulose (CMC, marketed 17 under the name Blanose ${ }^{\circledR}$, grade $7 \mathrm{LF} \mathrm{PH}, \mathrm{DS}=0.7, \mathrm{M}_{\mathrm{w}}=70 \mathrm{~kg} / \mathrm{mol}$ ) was kindly provided by 18 Hercules (France). The molecular weight distribution and the weight-average molecular weight 19 of the HA and CMC samples were determined by size exclusion chromatography using a Waters 20 GPC Alliance chromatograph (USA) equipped with a differential refractometer and a light 21 scattering detector (MALLS) from Wyatt (USA); the solutions were injected at a concentration of $221 \mathrm{mg} / \mathrm{mL}$ in $0.1 \mathrm{M} \mathrm{NaNO}_{3}$. The polydispersity index of the samples is $\mathrm{M}_{\mathrm{w}} / \mathrm{M}_{\mathrm{n}} \sim 1.5-2$. Pentenoic 23 anhydride, $N, N$-dimethylformamide (DMF), phosphate buffer saline (PBS, $\mathrm{pH} \sim 7.4), 2-(N-$ 24 morpholino)ethanesulfonic acid (MES), (3-aminopropyl)trimethoxysilane (APTS), $N$-ethyl- $N$ '-(3- 
1 dimethylaminopropyl)carbodiimide hydrochloride (EDC), N-hydroxysulfosuccinimide (sulfo-

2 NHS)were purchased from Sigma-Aldrich-Fluka (L'isled'Abeau, France). 2-hydroxy-1-[4-(2-

3 hydroxyethoxy)phenyl]-2-methyl-1-propanone (Irgacure 2959) was kindly provided by Ciba

4 Specialty Chemicals (Basel, Switzerland). All chemicals were used without any further

5 purification.

6 The peptides GRGDS, GRGDE, Ac-CGGNGEPRGDTYRAY-NH 2 and Ac-

7 CGGNGEPRGETYRAY-NH $\mathrm{NH}_{2}$ with $>85 \%$ purity (from manufacturer HPLC analysis), were

8 obtained from GeneCust Europe (Luxemburg). Poly(ethylene glycol)-bis(thiol) $\left(\mathrm{M}_{\mathrm{n}}=3400\right.$

$9 \mathrm{~g} / \mathrm{mol}$ ) was purchased from PEGWorks (USA). All chemicals were used without any further

10 purification. The water used in all experiments was purified by aElgaPurelab purification system,

11 with a resistivity of $18.2 \mathrm{M} \Omega \cdot \mathrm{cm}$.

12 Synthesis of pentenoate-modified HA (HA-p). HA (0.30 g, $0.75 \mathrm{mmol})$ was dissolved in

13 ultrapure water $(15 \mathrm{~mL})$ at $4{ }^{\circ} \mathrm{C}$ and the resulting mixture was kept at $4{ }^{\circ} \mathrm{C}$ under continuous

14 stirring overnight for complete dissolution. DMF $(10 \mathrm{~mL})$ was then added dropwise in order to

15 have a water/DMF ratio of (3:2, v/v).Pentenoic anhydride (0.411 g, $2.25 \mathrm{mmol})$ was added while

16 maintaining the $\mathrm{pH}$ between 8 and 9 (by adding $0.5 \mathrm{M} \mathrm{NaOH}$ ) for 4 hours. The reaction was kept

17 at $4{ }^{\circ} \mathrm{C}$ under continuous stirring for one night. After this time, $\mathrm{NaCl}$ was added to the reaction

18 mixture to have a $\mathrm{NaCl}$ concentration of $0.5 \mathrm{M}$. The polymer was precipitated by addition of

19 ethanol (water/ $\mathrm{EtOH}(\mathrm{v} / \mathrm{v})$ ratio of 2:3). After removal of the supernatant, the precipitate was

20 successively washed with mixtures of water/EtOH $(3: 7,1: 4, \mathrm{v} / \mathrm{v})$ and finally dissolved in

21 ultrapure water for a final purification by diafiltration (ultramembraneAmicon YM10) with

22 ultrapure water. The purified product was recovered by freeze-drying and characterized by ${ }^{1} \mathrm{H}$

23 NMR spectroscopy. The degree of substitution (DS, the average number of moles of substituents

24 per repeating unit of the polysaccharide)was determined to be $0.50 \pm 0.05$. 
1 Synthesis of pentenoate-modified CMC. CMC (0.30 g, $1.34 \mathrm{mmol})$ was dissolved in ultrapure

2 water $(15 \mathrm{~mL})$ at $4{ }^{\circ} \mathrm{C}$ and the resulting mixture was kept at $4{ }^{\circ} \mathrm{C}$ under continuous stirring

3 overnight for complete dissolution. DMF $(10 \mathrm{~mL})$ was then added dropwise in order to have a

4 water/DMF ratio of $(3: 2, \mathrm{v} / \mathrm{v})$. Pentenoic anhydride $(0.980 \mathrm{~g}, 5.36 \mathrm{mmol})$ was added while

5 maintaining the $\mathrm{pH}$ between 8 and 9 (by adding $0.5 \mathrm{M} \mathrm{NaOH}$ ) for 4 hours. The reaction was kept

6 at $4{ }^{\circ} \mathrm{C}$ under continuous stirring for one night. After this time, $\mathrm{NaCl}$ was added to the reaction

7 mixture to have a $\mathrm{NaCl}$ concentration of $0.5 \mathrm{M}$. The polymer was precipitated by addition of

8 ethanol (water/ EtOH (v/v) ratio of 2:3). After removal of the supernatant, the precipitate was

9 successively washed with mixtures of water/EtOH $(3: 7,1: 4, \mathrm{v} / \mathrm{v})$ and finally dissolved in

10 ultrapure water for a final purification by diafiltration (ultramembraneAmicon YM10) with

11 ultrapure water. The purified product was recovered by freeze-drying and characterized by ${ }^{1} \mathrm{H}$

12 NMR spectroscopy. The degree of substitution was determined to be $0.20 \pm 0.02$.

\section{Synthesis of HA-peptide and CMC-peptide conjugates.}

14 Pentenoate-modified HA or CMC $(0.100 \mathrm{~g})$ was dissolved in ultrapure water $(10 \mathrm{~mL}) .50 \mu \mathrm{L}$ of 15 an aqueous solution of Irgacure $2959(10 \mathrm{mg} / \mathrm{mL})$ was then added to the polysaccharide solution 16 to obtain a final photoiniator concentration of $5 \%(\mathrm{w} / \mathrm{v})$, followed by thepeptide containing a 17 thiol function. The amount of the peptide was adapted to the desired degree of substitution (see 18 Table 1). The mixture was exposed to light with a UV intensity of $20 \mathrm{~mW} / \mathrm{cm}^{2}$ for 5 min under 19 stirring. The product was purified by diafiltration (ultramembraneAmicon YM10) with ultrapure 20 water and was recovered by freeze-drying. The degree of substitution of the polysaccharide21 peptide conjugates was determined by ${ }^{1} \mathrm{H}$ NMR. 
1 The ${ }^{1} \mathrm{H}$ and ${ }^{13} \mathrm{C}$ NMR spectra of the polysaccharide derivatives dissolved in deuterium oxide

2 were performed at 25 or $80{ }^{\circ} \mathrm{C}$ (depending of the viscosity of the solution) using a Bruker

3 AVANCE III HD spectrometer operating at $400 \mathrm{MHz}\left({ }^{1} \mathrm{H}\right)$ and at $100 \mathrm{MHz}\left({ }^{13} \mathrm{C}\right)$. All ${ }^{1} \mathrm{H} \mathrm{NMR}$

4 spectra were recorded by applying a $45^{\circ}$ tip angle for the excitation pulse, and a $10 \mathrm{~s}$ recycle

5 delay for accurate integration of the proton signals. The ${ }^{13} \mathrm{C}$ NMR spectra were recorded by

6 applying a $45^{\circ}$ tip angle for the excitation pulse, and a $3 \mathrm{~s}$ recycle delay. All $2 \mathrm{D}$ experiments were

7 acquired using $2 \mathrm{~K}$ data points and 256 time increments. Chemical shifts are given relative to

8 external tetramethylsilane (TMS $=0 \mathrm{ppm}$ ) and calibration was performed using the signal of the

9 residual protons or carbons of the solvent as a secondary reference. Deuterium oxide was

10 obtained from SDS (Vitry, France). Details concerning experimental conditions are given in the

11 figure captions.

12 Photorheometry.

13 An AR2000Ex rheometer (TA Instruments Inc.) fitted with a UV-curing cell $(\lambda=365 \mathrm{~nm})$ and an

14 aluminum plate (diameter $19 \mathrm{~mm}$ ) was used for the in situ measurement of the viscoelastic

15 properties of the HA- and CMC-based hydrogels. Following deposition of $250 \mu \mathrm{L}$ of a mixture of

16 HA-peptide conjugate (or CMC-peptide conjugate), PEG-(SH) 2 and photoinitiator, the gap

17 between the flat quartz plate and the aluminum plate was initially $0.7 \mathrm{~mm}$ (measuring ambient

18 temperature). It was controlled during the experiments by maintaining the normal force at $0 \pm 0.1$

19 N. On each hydrogel, oscillatory time sweep and frequency sweep experiments were performed.

20 They were carried out at $25{ }^{\circ} \mathrm{C}$, with a film of silicone to avoid solvent evaporation. All the

21 dynamic rheological data were checked as a function of strain amplitude to ensure that the

22 measurements were performed in the linear viscoelastic region. In the oscillatory time sweep

23 experiments, the storage modulus $\left(G^{\prime}\right)$ and loss modulus $\left(G^{\prime}\right.$ ') were measured during a period of 
$1 \quad 25-30 \mathrm{~min}$ at a fixed frequency of $1 \mathrm{~Hz}$ and a fixed deformation of $3.5 \%$. Typically, after

2 deposition of the solution of the mixture of polymers in PBS between the plates and equilibration

3 for $1 \mathrm{~min}$, the solution was illuminated $(\lambda=365 \mathrm{~nm})$ for $25-30 \mathrm{~min}$ at a fixed light power $(20$

$4 \mathrm{~mW} / \mathrm{cm}^{2}$ ) leading to gelation. All measurements were done in triplicate. The photoinduced

5 crosslinking reaction was performed by adjusting the PEG-(SH) 2 amount with respect to HA and

6 CMC to obtain hydrogels having a similar elastic modulus (G') of $15000 \square 1500$ PaThe

7 thiol:CMC molar ratio used for gel formation was approximately two-times lower than the

8 thiol:HA molar ratio as the repeating unit of $\mathrm{CMC}$ is a monosaccharide whereas that of $\mathrm{HA}$ is a

9 disaccharide (see next section).

\section{Hydrogel immobilization}

11 For the cell culture experiments, hydrogels were covalently linked to the coverslips during photo-

12 crosslinking reactions by grafting pentenoate-modified HA or CMC on the coverslip prior to use.

13 The coverslip was modified with APTS as previously described. ${ }^{37}$ The modified slip with $-\mathrm{NH}_{2}$

14 groups was immersed in $2 \mathrm{~mL}$ of a solution of pentenoate-modified HA or CMC (3 mg/mL in 0.2

15 M MES, pH 4.75). A solution of sulfo-NHS $(30 \mathrm{~g} / \mathrm{L}, 100 \mu \mathrm{L})$ and a solution of EDC $(50 \mathrm{~g} / \mathrm{L}, 100$

$16 \mu \mathrm{L}$ ) were subsequently added. The coverslip was gently stirred at room temperature for $4 \mathrm{~h}$. The

17 slip was then rinsed with water and dried under a flow of nitrogen before use. The HA- and

18 CMC-based hydrogels were prepared by deposition of a solution of HA or CMC modified with

19 pentenoate groups and peptides $(75 \mu \mathrm{L},[\mathrm{HA}]=30 \mathrm{~g} / \mathrm{L}$ and $[\mathrm{CMC}]=30 \mathrm{~g} / \mathrm{L})$ containing Irgacure

$202959(5 \% \mathrm{w} / \mathrm{v})$ and PEG-(SH$)_{2}\left(2.1 \mathrm{mg}\left(0.61 \times 10^{-3} \mathrm{mmol}\right)\right.$ for $\mathrm{HA}$ and $0.9 \mathrm{mg}\left(0.26 \times 10^{-3} \mathrm{mmol}\right.$

21 for $\mathrm{CMC}),[\mathrm{SH}] /[$ pentenoate $]=0.5$ for $\mathrm{HA}$ and for $\mathrm{CMC}$ ) to the glass slip. The mixture was then

22 coated with a glass slide using $0.4 \mathrm{~mm}$-thick glass plate spacers and then exposed to UV-

23 irradiation $\left(20 \mathrm{~mW} / \mathrm{cm}^{2}, 20 \mathrm{~min}\right)$. Under such conditions, hydrogel disks with and without cell- 
1 adhesive peptides $\left(\mathrm{G}^{\prime}=15000 \pm 1500 \mathrm{~Pa}\right.$ )were prepared.After preparation, hydrogels were

2 transferred to cell culture media (Dulbecco's modified minimal essential medium, DMEM,

3 Invitrogen) supplemented with $50 \mathrm{U} / \mathrm{mL}$ penicillin, and $50 \mathrm{mg} / \mathrm{mL}$ streptomycin and left for $12 \mathrm{~h}$

4 for equilibrium before cell culture studies. Media was refreshed after $12 \mathrm{~h}$ to remove any

5 remaining monomer or initiator.

6 Generation of preosteoblast cell line.

7 To generate preosteoblast cell lines,primary osteoblasts (passage 2) were immortalized by 8 infection with adenovirus expressing the large SV40 T antigen, ${ }^{38}$ Immortalized cells were cloned

9 and each clone tested for its ability to differentiate as viewed alkaline phosphataseexpression and

10 aptitude to mineralize ECM, ${ }^{39}$ as previously described ${ }^{40}$. They were cultivated under the standard

11 conditions in DMEM supplemented in $10 \%$ fetal calf serum in a $5 \% \mathrm{CO}_{2}$ atmosphere.

\section{Cell labeling and quantification of cell spreading}

13 For quantifying the projected areas of spread cells, the cells were fixed with a solution of $4 \%$

$14(\mathrm{w} / \mathrm{v})$ of paraformaldehyde in $0.2 \mathrm{M}$ phosphate buffer $(\mathrm{pH}=7.2)$ for $10 \mathrm{~min}$ at room temperature.

15 After 3 washes in TRIS saline buffer (TBS), the cells were incubated in DMEM supplemented 16 with $0.5 \%$ of Vybrant ${ }^{\mathrm{TM}}$ DIL cell labeling solution for $15 \mathrm{~min}$ at $37^{\circ} \mathrm{C}$ according to the

17 manufacturer's instructions (Life Technologies, St Aubin, France). The cells were washed 3 times

18 in PBS and mounted under a coverslip with $10 \mu \mathrm{L}$ of mounting solution for epifluorescence

19 observations. Observation were carried out with anOlympus BX 51 microscope (Olympus

20 Europe Hamburg, Germany) equipped with a Plan NeoFluar 20X (N.A. 0.5) objective. Areas

21 were determined with Metamorph software (Molecular Devices, Sunyvale, CA USA) at a

22 magnification of 200X. Statistical analyses were carried out with R software (The R Project for

23 Statistical Computing, http://www.r-project.org/). 
2 DNA synthesis detection in proliferating cells was based on the incorporation of 5-ethynyl-2-

3 deoxyuridine (EdU) and its subsequent detection by a fluorescent azide through a $\mathrm{Cu}(\mathrm{I})$-catalyzed

$4[3+2]$ cycloaddition reaction. ${ }^{41}$ Cells were grown on hydrogel substrates for 24 hin DMEM

5 supplemented with $10 \%$ fetal calf serum, penicillin, and streptomycin. EdU was added to the

6 culture media at $10 \mu \mathrm{M}$ (Stock 10mM), for 1-2 hour. After labeling, cells were washed with PBS.

7 Cells were fixed by using a standard paraformaldehyde $4 \%$ for $10 \mathrm{~min}$. Subsequently, cells were

8 rinsed once with TBS and stained by incubating for $30 \mathrm{~min}$ with $0.5-1 \mathrm{~mL} /$ well with $6 \mathrm{~mL}$ of

9 afreshly prepared staining mix made of $110 \mathrm{mMTris} \mathrm{pH} 8.5,1 \mathrm{mM} \mathrm{CuSO}, 60 \mathrm{mM}$ ascorbic acid,

$1010 \mu \mathrm{M}$ Alexa azido (from stock solution in DMSO).After staining, the cells were washed three

11 times with TBS with $0.2 \%$ Triton $\mathrm{X}-100$. The fraction of fluorescent (dividing) cells was

12 estimated on at least 10 independent frames.

\section{Alizarin Red-S Protocol for Mineralization}

14 Pre-osteoblasts $80-90 \%$ confluent were placed into osteogenic media made of regular DMEM 15 medium with $10 \%$ FetalCloneII (Hyclone), supplemented with 10mM $\beta$-glycerophosphate, and $16100 \mu \mathrm{M}$ of ascorbic acid. Culture was continued for 21 days. Mineralization was already observed 17 at 10 days. The calcified mineral deposits were stained with Alizarin Red-S (AR-S) using the 18 protocol developed by Gregory et al. ${ }^{42}$ Briefly, separate 12 -well plates after 8, 11, 15 and 24 days 19 in culture were washed gently with PBS and fixed in $10 \%$ (v/v) formaldehyde for 15 min at 20 room temperature. After washing twice with excess deionized water, the samples were immersed 21 in $0.5 \mathrm{~mL}$ of $40 \mathrm{mM}$ AR-S (pH 4.1) for $20 \mathrm{~min}$ with gentle shaking. Then, the samples were 22 washed four times with excess deionized water for $5 \mathrm{~min}$ each with shaking. The wet samples 23 were subsequently imaged using a stereo microscope Olympus SZX10v with an angled 
1 illumination source (Schott K1500). For quantification, threshold of the staining on digital

2 images allowed the measurement of mineralized areas using Metamorph software.

$4 \quad$ RESULTS

5 Synthesis of HA-peptide and CMC-peptide conjugates. To fabricate HA and CMC hydrogels

6 (Figure 1), we first functionalized HA and $\mathrm{CMC}$ with pentenoate groups by reaction of the

7 hydroxyl groups of the polysaccharides with 4-pentenoic anhydride as previously described. ${ }^{27}$ In

8 these reactions, the feed molar ratios of anhydride to the polysaccharide repeat unit were adjusted

9 in a way to obtain HA-pentenoate (HA-p) and CMC-pentenoate (CMC-p) derivatives having a

10 degree of substitution (DS) of 0.50 and 0.20 , respectively (see experimental section). The DS was

11 approximately two-times lower in the case of CMC because the repeating unit of this

12 polysaccharide is only composed of one sugar.

13 Then, the resulting HA-p and CMC-p derivatives were reacted withthe 5-mer peptide GRGDS 14 and the 15-mer peptide bsp-RGD via photoinducedthiol-ene reactions between the thiol of the 15 terminal mercaptopropionic acid in GRGDS and the terminal cysteine in bsp-RGD and, the 16 alkene function of pentenoate. In order to tune the cell-adhesive ligand density while maintaining 17 a constant elastic modulus, the peptides were added in equivalents of no greater than $50 \%$ of the 18 total number of alkene groups of HA and CMC.In this way, the double bonds after peptide 19 conjugation are in sufficient numbers to maintain the same crosslinking density while increasing 20 the peptide density. Integrin specific cell response was controlled by grafting non-adhesion 21 peptides containing the RGE sequence instead of RGD: GRGES (Gly-Arg-Gly-Glu-Ser) and bsp22 RGE (Ac-Cys-Gly-Gly-Asn-Gly-Glu-Pro-Arg-Gly-Glu-Thr-Tyr-Arg-Ala-Tyr-NH ${ }_{2}$. Following 23 this coupling step, the HA-peptide and CMC-peptide conjugates were purified by diafiltration 24 and analyzed by ${ }^{1} \mathrm{H}$ NMR to check their structural integrity and precisely determine their DS (see 
1 Table 1 and ${ }^{1} \mathrm{H}$ NMR spectrain Supporting Information (Figures S1-S10)). The DS was

2 calculated by digital integration of well-defined signals of the peptide and of the polysaccharides

3 (Figures S3, S6, S8, S10). Of note, the DS values could be confirmed by analyzing the

4 disappearance of the signals of the protons associated with the double bonds (Figures S3, S6, S8,

5 S10).Comparison between the feed molar ratios of peptide to pentenoate and the DS of the

6 modified polysaccharides (Table 1) indicated that the peptides were grafted on HA and on CMC

7 in quite satisfactory yields (66-91\%). The final crosslinking reaction step was performed by

8 adjusting the PEG-( $\mathrm{SH})_{2}$ amount at a fixed amount of HA or CMC. The HA- and CMC-based

9 hydrogels were prepared using, respectively, a thiol:HA disaccharide repeating unit molar ratio of

$10 \quad 0.25$ and a thiol:CMC monosaccharide repeating unit molar ratio of 0.10 in order to obtain

11 hydrogels having a similar elastic modulus (G') of $15000 \pm 1500 \mathrm{~Pa}$. This value was chosen based

12 on our previous results showing the ability of pre-osteoblasts to attach and partially spread on a

13 HA-based hydrogel having an elastic modulus of $17000 \mathrm{~Pa}$.

14 Pre-osteoblast spreading.Preliminary biological studies were performed to investigate the effect

15 of the nature of the peptide ligand and its density as well as of the polysaccharide backbone on

16 cell spreading at constant stiffness. To this end, pre-osteoblasts were seeded on the hydrogels

17 prepared from the HA and CMC derivatives listed in Table 1 as well as from HA-p and CMC-p,

18 and cultured overnight in DMEM supplemented with $10 \%$ fetal calf serum. Cell spreading was

19 analyzed by statistical measurements of the cell projected area using Vybrant ${ }^{\mathrm{TM}}$ DIL staining and

20 Metamorph image analysis software (see experimental section).

21 Figure 2A shows that the HA hydrogellacking peptides was able to sustain some but limited cell

22 spreading (in good agreement with previous reports ${ }^{25}$ ) while under identical conditions, pre-

23 osteoblasts seeded on the gel derived from CMC-p remained rounded up. In contrast, significant

24 spreading on CMC and HA gels was obtained by incorporation of the GRGDS and bsp-RGD 
1 peptides. A marked difference in cell spreading efficiency could be observed for the two peptides

2 with hydrogels based on CMC hydrogels (Figures2A and 2B); Thebsp-RGD-endowed gels

3 sustained cell spreading in a more effective way. Surprisingly, for all hydrogels bell shaped

4 adhesion curves were obtained depending on peptide densities, and optimalpeptide concentration

5 varied according to the polysaccharide backbone used andthepeptide sequence. For instance,

6 optimal GRGD peptide density was higher than the bsp-RGD one to induce the same degree of

7 spreading (Figure 2B). Since the control GRGES or bsp-RGE peptides promote little or

8 nosignificant spreading when incorporated on HA and CMC, respectively,similarly to non grafted

9 gels (Figure 2B), one can conclude that the observed pre-osteoblast responses are

10 mostlydependent on the grafted peptide and likely due to integrin surface receptors.

11 The decrease in cell binding at high ligand concentrations may result from a negative effect of

12 neighboring ligands on binding as previously reported ${ }^{43}$.Assuming that the cells can only access

13 the top $10 \mathrm{~nm}$ of the hydrogel, the peptide surface concentrations were found to be between 0.7

14 and $12.2 \mathrm{pmol} / \mathrm{cm}^{2}$ (tableau 1). Rezania et al. determined the minimum concentration of bsp-

15 RGD required for spreading of rat-derived calvarial osteoblasts on quartz surfaces functionalized

16 with bsp-RGD to be $\sim 0.6 \mathrm{pmol} / \mathrm{cm}^{2} .{ }^{29}$ Although the actual minimum concentration of bsp-RGD

17 ligands required at the $\mathrm{HA}$ and $\mathrm{CMC}$-based gel surfaces for spreading of pre-osteoblasts was not

18 identified, one can however notethat the optimal concentration required for maximum spreading

19 on the bsp-RGD endowed HA- and CMC hydrogels is 4.5 fold the limit literature value.

20 All together, these results highlight that by exploiting the design flexibility of the characteristics

21 offered by these biomimetic hydrogels, it may be possible to selectively engineer their biological

22 properties. The gels based on HA-11RGD and on HA-4bsp-RGDappeared to bethe most efficient

23 substrates for promoting cell spreadingafter one night (marked in yellow in Figure 2B). The

24 CMC-based substrates were found to be effective in promoting cell spreading only if they 
1 contained bsp-RGD ligands. Since the optimal cell/substrate interaction depends not only on both

2 the nature of the peptide used for functionalization and its surface concentration, but also on the

3 polysaccharide backbone, these experimental conditions must clearly be determined when

4 comparing the biological properties of hydrogels.

5 Cell response proliferation and differentiation during long term culture on hydrogels. To

6 better understand how the types of biomimetic modification and polysaccharide matrix might be

7 used for best biocompatibility, proliferation assays where carried out after a $24 \mathrm{~h}$ pre-culture and

8 measured by EdU staining of dividing cells (see experimental section). The results presented in

9 Figure 3, clearly indicated that at the optimal DS allowing to support efficient cell spreading,

10 both RGD and bsp-RGD triggered a high proliferation rate, and that RGD-grafted HA gels

11 allowed a better cell proliferation rate that the CMC counterpart.Analysis of matrix

12 mineralization in long term culture (a read-out of osteogenic differentiation) was carried out with

13 hydrogels that support optimized cell spreading, namely gel substrates based on HA-11RGD,

14 HA-4bsp-RGD and CMC-4bsp-RGD for 21 days. Observing surface-bound pre-osteoblasts

15 during this period, it was found that cells not bound to surfaces died after a few days, the others

16 were proliferating and formed a monolayer before stopping dividingand initializing

17 differentiation.

18 At different time points ECM mineralization was examined on representative cell cultures by

19 staining calcium deposition using Alizarin Red S (Figure 4). Significantly more mineral

20 deposition (red to dark brown staining depending on the amount of calcium) on the gel surfaces

21 was detected for HA-based gels after 10 and 21 days (Figure 4). This was confirmed by a

22 statistically analysis of 10 distinct fields for quantification of the areas of positively stained

23 deposits (Figure 5). Significantly larger areas of mineral deposits on HA-based gels compared to

24 the CMC-based hydrogel were observed after 10 and 21 days although mineralization nodules 
1 were quite visible on CMC gels at 21 days. Furthermore, comparison between the HA-4bsp-RGD

2 and HA-11RGD substrates indicates a higher degree of mineralization for the gel displaying bsp-

3 RGD ligands. Overall these results indicate that HA-based hydrogels promote osteogenic

4 development when combined with peptide ligands that facilitate integrin-mediated binding matrix

5 mineralization. Considering the significant difference in the optimal DS of the two HA-peptide

6 conjugates, it can clearly be concluded that the bsp-RGD-endowed hydrogel sustained cellular

7 proliferation and mineralization in a more effective way.

9 DISCUSSION

10 In this study, we synthesized and characterized a new class of HA- and CMC-based hydrogels 11 with independently tunable stiffness and adhesive peptide functionality and used these soft

12 hydrogels to study the dependence of spreading and long-term function of pre-osteoblast cells on

13 changes in matrix chemical composition at fixed gel stiffness. Taking advantage of the flexibility 14 of thiol-ene reactions, we showed the ability to incorporate short peptides (5-mer derivatives) as 15 well as long peptides (15-mer derivatives) in nearly $100 \%$ yields and precisely quantify their 16 incorporation into hydrogels by a careful characterization of peptide-modified polysaccharides by

$17{ }^{1}$ H NMR spectroscopy. Pre-osteoblast seeded on the hydrogels spread in a manner that was 18 strongly dependent on ligand density. Surprisingly, increasing the density of the adhesive peptide 19 anchors did not result in a plateau of initial cell spreading but rather in a bell shaped cell response 20 which varies with the nature of both polysaccharide backbone and functional peptide. When bsp21 RGD was incorporated into HA and CMC gels instead of GRGDS, the optimal average peptide 22 density for cell spreading was shifted to lower values, which can be attributed either to a better 23 accessibility of the bsp-RGD possibly due the increased chain length, or to a better integrin 24 signaling or/and clustering. It is therefore very important to determine key matrix design 
1 relationships such as the effects of presentation of adhesion peptides in terms of type and density,

2 nature of polysaccharide backboneused for gel formation and crosslink density leading to optimal

3 cell response, before drawing conclusions on the biocompatibility of a specific hydrogel.

4 We also demonstrated that for pre-osteoblasts of which adhesion to fibronectin is mediated by

5 significant interactions with both the $\alpha_{5} \beta_{1}$ and $\alpha_{\mathrm{v}}$ integrins, ${ }^{44}$ hyaluronic acid synergizes with

6 integrin occupancy not only to promote cell spreading under short term culture, but also

7 osteoblast differentiation and mineralization under long term culture. This specific cell response

8 to RGD-endowed HA gels suggests that there is an interplay between HA receptors and RGD-

9 specific integrins(i.e. $\alpha_{5} \beta_{1}$ and $\left.\alpha_{v} \beta_{3}\right) .{ }^{24}$ Although several investigators havepreviously reported on

10 the development of HA-based hydrogelswith tunable stiffness and ligand density, ${ }^{32-36}$ the likely

11 involvement of HA receptors namely CD44 and RHAMM along with RGD-binding integrins has

12 only recently been reported. ${ }^{24,45}$ Our work clearly shows that in HA hydrogels, the polysaccharide

13 moiety is not solely a passive scaffold that presents the active peptides but is an active player in

14 cell microenvironment to control and sustain cell activity.

15 In this regard, our strategy described here for synthesizing well-defined hydrogels that combine

16 the intrinsic properties of mammalian polysaccharides and cell adhesive ligands isolated from

17 extracellular matrix proteins, provides a versatile platform to get a better insight into the

18 molecular mechanisms that underlie cell-specific responses to naturally-derived hydrogels with 19 respect to key chemical and mechanical attributes.

\section{CONCLUSIONS}

22 The strategy for the synthesis of bioactive polysaccharide hydrogels described in this work 23 represents a versatile platformto evaluate the effect of peptides, their density and 
1 thepolysaccharide matrix on cellular adhesion and function with minimal contribution from non-

2 specific interactions. Using these substrates, the residuesflanking the RGD sequence in peptides

3 was shown to significantly influence the spreading and long-term function of pre-osteoblast cells.

4 Future studies will focus on engineering gels with controlled porosity to promote cell infiltration

5 into gels as a bioactive scaffold for osteogenesis. In addition, naturally-derived hydrogels with

6 controlled biological interactions conferred by tissue-specific ligands may be applied to the

7 engineering of a variety of other tissue types.

9 ACKNOWLEDGMENTS

10 This work was financially supported by the Joseph Fourier University (Grenoble) and the

11 Agencenationale de la recherche(ANR-TecSan 2009 program). R.A.V. is a Junior Member of the

12 InstitutUniversitaire de France, whose support is gratefully acknowledged. The authors thank

13 Isabelle Jeacomine for technical help in the NMR analysis of the peptides and the peptide14 modified polysaccharides.

\section{Supporting Information Available:}

$17{ }^{1} \mathrm{H}$ NMR spectra of GRGDS, GRGDE, HA-RGD with different DS, two-dimensional ${ }^{1} \mathrm{H},{ }^{13} \mathrm{C}$ 18 HSQC spectrum of bsp-RGD, HA-bsp-RGD with different DS, CMC-RGD with different DS, 19 CMC-bsp-RGD with different DS. This material is available free of charge via the Internet at 20 http://pubs.acs.org.

22 REFERENCES 
1. Hunt, J. A.; Chen, R.; van Veen, T.; Bryan, N. J. Mater. Chem. B 2014, 2, 5319-5338.

2. Seliktar, D. Science 2012, 336, 1124-1128.

3. Slaughter, B. V.; Khurshid, S. S.; Fisher, O. Z.; Khademhosseini, A.; Peppas, N. A. Adv. Mater. 2009, 21, 3307-3329.

4. Engler, A. J.; Sen, S.; Sweeney, H. L.; Discher, D. E. Cell 2006, 126, 677-689.

5. Trappmann, B.; Chen, C. S. Curr. Opin. Biotechnol. 2013, 24, 948-953.

6. Paszek, M. J.; Zahir, N.; Johnson, K. R.; Lakins, J. N.; Rozenberg, G. I.; Gefen, A.; Reinhart-King, C. A.; Margulies, S. S.; Dembo, M.; Boettiger, D.; Hammer, D. A.; Weaver, V. M. Cancer Cell 2005, 8, 241-254.

7. Dicker, K. T.; Gurski, L. A.; Pradhan-Bhatt, S.; Witt, R. L.; Farach-Carson, M. C.; Jia, X. Acta Biomater. 2014, 10, 1558-1570.

8. Fraser, J. R.; Laurent, T. C.; Laurent, U. B. J. Intern.Med.1997, 242, 27-33.

9. Charlot, A.; Auzely-Velty, R. Macromolecules 2007, 40, 9555-9563.

10. Kadi, S.; Cui, D.; Bayma, E.; Boudou, T.; Nicolas, C.; Glinel, K.; Picart, C.; Auzély-Velty, R. Biomacromolecules 2009, 10, 2875-2884.

11. Lam, J.; Truong, N. F.; Segura, T. Acta Biomater. 2014, 10, 1571-1580.

12. Leach, J. B.; Bivens, K. A.; Patrick, C. W., Jr.; Schmidt, C. E. Biotechnol. Bioeng. 2003, 82, 578-589.

13. Burdick, J. A.; Prestwich, G. D. Adv. Mater.2011, 23, H41-H56.

14. Xu, X.; Jha, A. K.; Harrington, D. A.; Farach-Carson, M. C.; Jia, X. Soft Matter 2012, 8, 3280-3294.

15. Ross, T. D.; Coon, B. G.; Yun, S.; Baeyens, N.; Tanaka, K.; Ouyang, M.; Schwartz, M. A. Curr. Opin. Cell Biol. 2013, 25, 613-618.

16. Rivera, J.; Lozano, M. L.; Navarro-Nunez, L.; Vicente, V. Haematologica 2009, 94, 700711.

17. Kinashi, T. Methods Mol Biol 2012, 757, 261-78.

18. Vicente-Manzanares, M.; Choi, C. K.; Horwitz, A. R. J. Cell Sci. 2009, 122, 199-206.

19. De Arcangelis, A.; Georges-Labouesse, E. Trends Genet. 2000, 16, 389-395.

20. Lesley, J.; Hyman, R.; Kincade, P. W. Adv. Immunol. 1993, 54, 271-335.

21. Turley, E. A.; Austen, L.; Vandeligt, K.; Clary, C. J. Cell Biol.1991, 112, 1041-7.

22. Borowsky, M. L.; Hynes, R. O. J. Cell Biol. 1998, 143, 429-442.

23. McCourt, P. A. G.; Ek, B.; Forsberg, N.; Gustafson, S. J. Biol. Chem. 1994, 269, 30081-4.

24. Chopra, A.; Murray, M. E.; Byfield, F. J.; Mendez, M. G.; Halleluyan, R.; Restle, D. J.; RazBen Aroush, D.; Galie, P. A.; Pogoda, K.; Bucki, R.; Marcinkiewicz, C.; Prestwich, G. D.; Zarembinski, T. I.; Chen, C. S.; Pure, E.; Kresh, J. Y.; Janmey, P. A. Biomaterials 2014, 35, 71-82.

25. Hachet, E.; Van Den Berghe, H.; Bayma, E.; Block, M. R.; Auzély-Velty, R. Biomacromolecules 2012, 13, 1818-1827.

26. Alsberg, E.; Anderson, K. W.; Albeiruti, A.; Franceschi, R. T.; Mooney, D. J. J. Dent. Res. 2001, 80, 2025-2029.

27. Mergy, J.; Fournier, A.; Hachet, E.; Auzély-Velty, R. J. Polym. Sci. Polym. Chem. 2012, 50, 4019-4028.

28. Hersel, U.; Dahmen, C.; Kessler, H. Biomaterials 2003, 24, 4385-4415.

29. Rezania, A.; Healy, K. E. J. Biomed. Mater. Res. 2000, 52, 595-600.

30. MacNeil, R. L.; Berry, J.; D'Errico, J.; Strayhorn, C.; Piotrowski, B.; Somerman, M. J. Connect Tissue Res 1995, 33, 1-7. 
31. Drevelle, O.; Bergeron, E.; Senta, H.; Lauzon, M.-A.; Roux, S.; Grenier, G.; Faucheux, N. Biomaterials 2010, 31, 6468-76.

32. Seidlits, S. K.; Khaing, Z. Z.; Petersen, R. R.; Nickels, J. D.; Vanscoy, J. E.; Shear, J. B.; Schmidt, C. E. Biomaterials 2010, 31, 3930-3940.

33. Marklein, R. A.; Burdick, J. A. Soft Matter 2010, 6, 136-143.

34. Lei, Y.; Gojgini, S.; Lam, J.; Segura, T. Biomaterials 2010, 32, 39-47.

35. Ghosh, K.; Pan, Z.; Guan, E.; Ge, S.; Liu, Y.; Nakamura, T.; Ren, X.-D.; Rafailovich, M.; Clark, R. A. F. Biomaterials 2006, 28, 671-679.

36. Ananthanarayanan, B.; Kim, Y.; Kumar, S. Biomaterials 2011, 32, 7913-23.

37. Destaing, O.; Planus, E.; Bouvard, D.; Oddou, C.; Badowski, C.; Bossy, V.; Raducanu, A.; Fourcade, B.; Albiges-Rizo, C.; Block, M. R. Mol. Biol. Cell 2010, 21, 4108-4119.

38. Faessler, R.; Pfaff, M.; Murphy, J.; Noegel, A. A.; Johansson, S.; Timpl, R.; Albrecht, R. J. Cell Biol. 1995, 128, 979-88.

39. Mansukhani, A.; Bellosta, P.; Sahni, M.; Basilico, C. J. Cell Biol. 2000, 149, 1297-1308.

40. Bouvard, D.; Aszodi, A.; Kostka, G.; Block, M. R.; Albiges-Rizo, C.; Fassler, R. Development 2007, 134, 2615-2625.

41. Salic, A.; Mitchison, T. J. Proc. Natl. Acad. Sci. U. S. A. 2008, 105, 2415-2420.

42. Gregory, C. A.; Gunn, W. G.; Peister, A.; Prockop, D. J. Anal. Biochem. 2004, 329, 77-84.

43. Kantlehner, M.; Schaffner, P.; Finsinger, D.; Meyer, J.; Jonczyk, A.; Diefenbach, B.; Nies, B.; Holzemann, G.; Goodman, S. L.; Kessler, H. ChemBioChem 2000, 1, 107-114.

44. Lee, M. H.; Adams, C. S.; Boettiger, D.; DeGrado, W. F.; Shapiro, I. M.; Composto, R. J.; Ducheyne, P. J. Biomed. Mater. Res., Part A 2007, 81A, 150-160.

45. Gares, S. L.; Pilarski, L. M. Dev. Immunol. 2000, 7, 209-225. 
1 Figure 1. Schematic representation of the synthesis of polysaccharide-peptide conjugates and

2 their cross-linking to form hydrogels using thiol-ene photochemistry.

4 Figure 2.Pre-osteoblast attachment and spreading on HA- and CMC-based hydrogels as a

5 function of presentation of adhesion peptides in terms of type and density.A)phase contrast

6 observations carried out on living cells with a Zeiss 100M Axiovert microscope equipped with a

7 plan 10X objective (N.A 0.25). Bar is $60 \mu \mathrm{m}$. B)cell spreading quantification. After cell fixation

8 with paraformaldehyde, cells were labeled with Vybrant ${ }^{\mathrm{TM}}$ DIL lipophilic tracer. Observations of

9 the fluorescent cells were carried out with an Olympus BX51 epifluorescent microscope

10 equipped with a Plan NeoFluar 20X objective (N.A. 0.50). The images threshold value was

11 adjusted to fit the cells limits and the projected cell areas were determined with Metamorph

12 software. Statistical analyses and box plots were performed with the $\mathrm{R}$ software $(n=60)$. The

13 bottom and top of the box are the $25^{\text {th }}$ and $75^{\text {th }}$ percentile (the lower and upper quartiles,

14 respectively), and the band near the middle of the box is the $50^{\text {th }}$ percentile (median). The ends of

15 the whiskers represent the lowest datum still within 1.5 Inter Quantile Range of the lower

16 quartile, and the highest datum still within 1.5 Inter Quantile Range of the upper quartile. The DS

17 of the HA-peptide and CMC-peptide conjugates is indicated above the boxes in red color. The

18 DS values giving rise to the highest degree of spreading are marked in yellow.

20 Figure 3. Cell proliferation on peptide-modified HA and CMC hydrogels with DS promoting cell 21 spreading: HA-11RGD, HA-4bsp-RGD and CMC-4bsp-RGD (see Figure 2)after $24 \mathrm{~h}$ of pre-

22 culture.Error bar represents mean \pm standard deviation. The analysis of 10 independent fields 
1 under each experimental conditions represented the analysis of more than 100 cells. Data on two 2 experiments were pooled to allow student tests.

3 Figure 4. Digital photographs of representative Alizarin Red-S stained cell monolayers on 4 peptide-modified hydrogels after 0,10 , and 21 days in culture in the osteogenic medium. The red 5 to dark brown areas represent the calcified deposits. Color intensity reflects the amount of 6 hydroxyapatite deposition.After 21 days the HA-based hydrogels showed higher degrees of 7 mineralization than the CMC-based hydrogel. Bar is $200 \mu \mathrm{m}$.

9 Figure 5. Area quantification of the calcified ECM after 0, 10, and 21 days in culture on 10 10 independent fields.The HA-based hydrogels displayed significantly greater mineralization than 11 the CMC-hydrogel on days 10 and 21. Error bar represents mean \pm standard deviation. 
1 Table 1. List of peptide sequences and of polysaccharide (PS)-peptide conjugates prepared by

2 thiol-ene chemistry

\begin{tabular}{|c|c|c|c|c|c|c|}
\hline PS & $\begin{array}{l}\text { Peptide/ } \\
\text { Peptide sequence }\end{array}$ & $\begin{array}{l}\text { [peptide]/ } \\
\text { [PS repeat } \\
\text { unit] }\end{array}$ & $\begin{array}{l}\text { DS } \\
(\% \text { peptide })^{\mathrm{a}}\end{array}$ & Name & $\begin{array}{l}\text { Coupling } \\
\text { yield }^{\mathrm{b}}\end{array}$ & $\begin{array}{l}\text { Peptide } \\
\text { surface } \\
\text { density }^{c}\end{array}$ \\
\hline \multirow[t]{13}{*}{ HA-p } & GRGDS & 0.04 & 3 & HA-3RGD & 75 & 2.0 \\
\hline & \multirow[t]{3}{*}{$\mathrm{HS}-\mathrm{CH}_{2}-\mathrm{CH}_{2}-\mathrm{CO}-\mathrm{NH}-\mathrm{GRGDS}$} & 0.07 & 6 & HA-6RGD & 85 & 4.1 \\
\hline & & 0.12 & 11 & HA-11RGD & 91 & 7.5 \\
\hline & & 0.20 & 18 & HA-18RGD & 90 & 12.2 \\
\hline & bsp-RGD & 0.015 & 1 & HA-1bsp-RGD & 66 & 0.7 \\
\hline & \multirow[t]{4}{*}{ Ac-CGGNGEPRGDTYRAY } & 0.03 & 2 & HA-2bsp-RGD & 66 & 1.2 \\
\hline & & 0.06 & 4 & HA-4bsp-RGD & 66 & 2.7 \\
\hline & & 0.09 & 7 & HA-7bsp-RGD & 77 & 5.5 \\
\hline & & 0.15 & 12 & HA-12bsp-RGD & 80 & 8.2 \\
\hline & GRGES & 0.08 & 6 & HA-6RGE & 75 & 4.1 \\
\hline & HS-CH$-\mathrm{CH}_{2}-\mathrm{CO}-\mathrm{NH}-\mathrm{GRGES}$ & & & & & \\
\hline & bsp-RGE & 0.06 & 4 & HA-4bsp-RGE & 66 & 2.7 \\
\hline & Ac-CGGNGEPRGETYRAY & & & & & \\
\hline \multirow{8}{*}{$\begin{array}{l}\text { CMC- } \\
\mathrm{p}\end{array}$} & \multirow[t]{2}{*}{ GRGDS } & 0.04 & 3 & CMC-3RGD & 75 & 3.9 \\
\hline & & 0.07 & 6 & CMC-6RGD & 85 & 7.7 \\
\hline & \multirow[t]{5}{*}{ bsp-RGD } & 0.015 & 1 & CMC-1bsp-RGD & 66 & 1.2 \\
\hline & & 0.03 & 2 & CMC-2bsp-RGD & 66 & 2.5 \\
\hline & & 0.05 & 4 & CMC-4bsp-RGD & 80 & 5.0 \\
\hline & & 0.08 & 6 & CMC-6bsp-RGD & 75 & 7.4 \\
\hline & & 0.12 & 9 & CMC-9bsp-RGD & 75 & 11.2 \\
\hline & bsp-RGE & 0.05 & 3 & CMC-3bsp-RGE & 60 & 3.7 \\
\hline
\end{tabular}

3 adetermined from ${ }^{1} \mathrm{H}$ NMR spectroscopy; ${ }^{\mathrm{b}}$ calculated by dividing $(0.01 \times \mathrm{DS})$ by the feed ratio

4 [peptide]/[PS repeat unit]; ${ }^{c}$ calculated by assuming that the cells can only access the top $10 \mathrm{~nm}$ of the

5 hydrogel.

6 


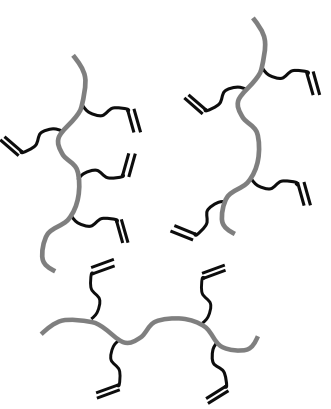

HA-p or CMC-p

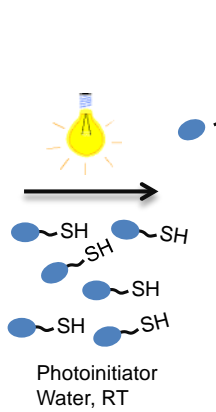

Water, RT

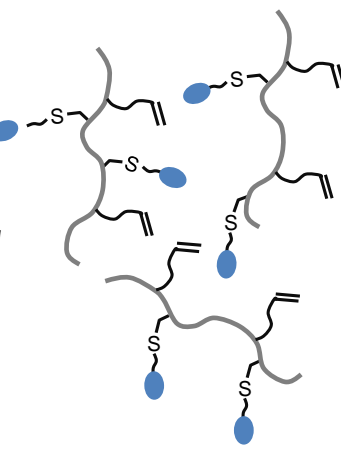

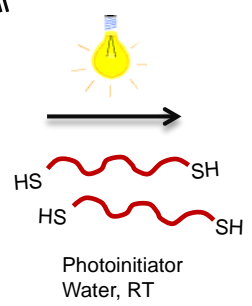

.
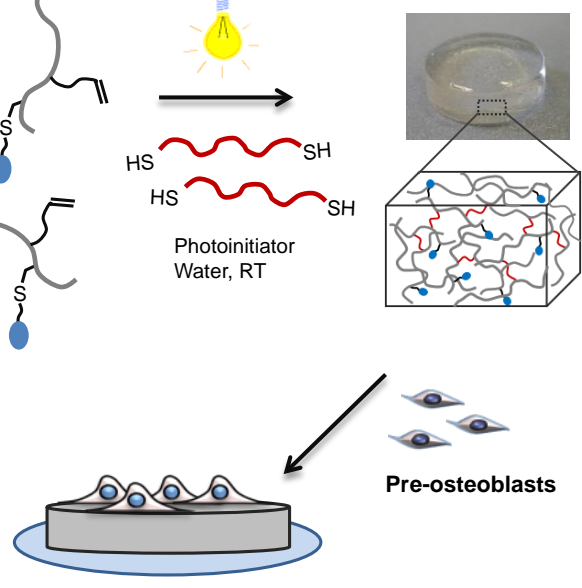

${ }_{\mathrm{HS}} \sim \sim_{\mathrm{SH}} \equiv \mathrm{HS}_{\mathrm{O}}\left(\mathrm{O}_{\mathrm{m}} \mathrm{\gamma}_{\mathrm{SH}}\right.$

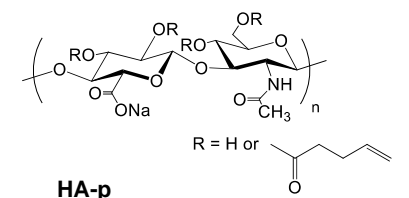

HA-p

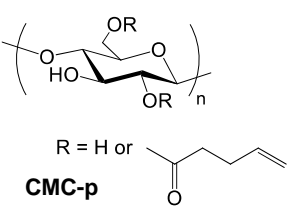

$\sim \mathrm{SH}$

- 1 - $\mathrm{CH}_{2}-\mathrm{CH}_{2}-\mathrm{CO}-\mathrm{NH}$ - GRGDS (denoted as "RGD")

or Ac-CGGNGEPRGDTYRAY (denoted as "bsp-RGD")

or $\mathrm{HS}-\mathrm{CH}_{2}-\mathrm{CH}_{2}$-CO-NH- GRGES (denoted as "RGE")

or Ac-CGGNGEPRGETYRAY (denoted as "bsp-RGE") 

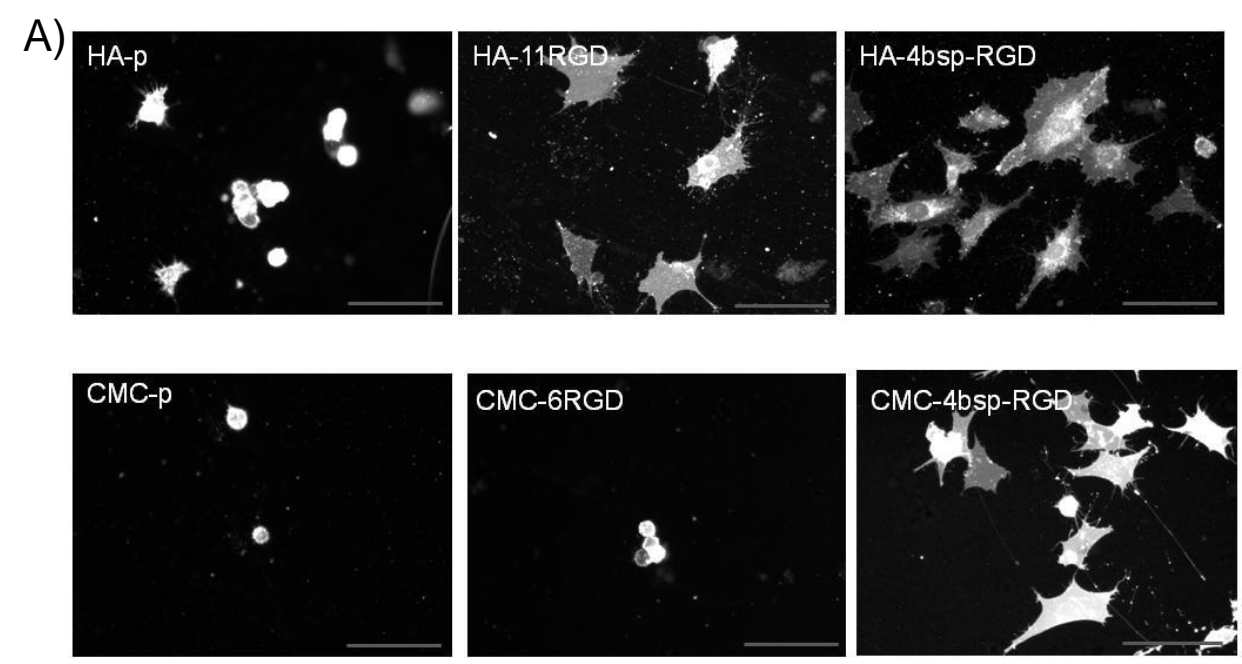

B)

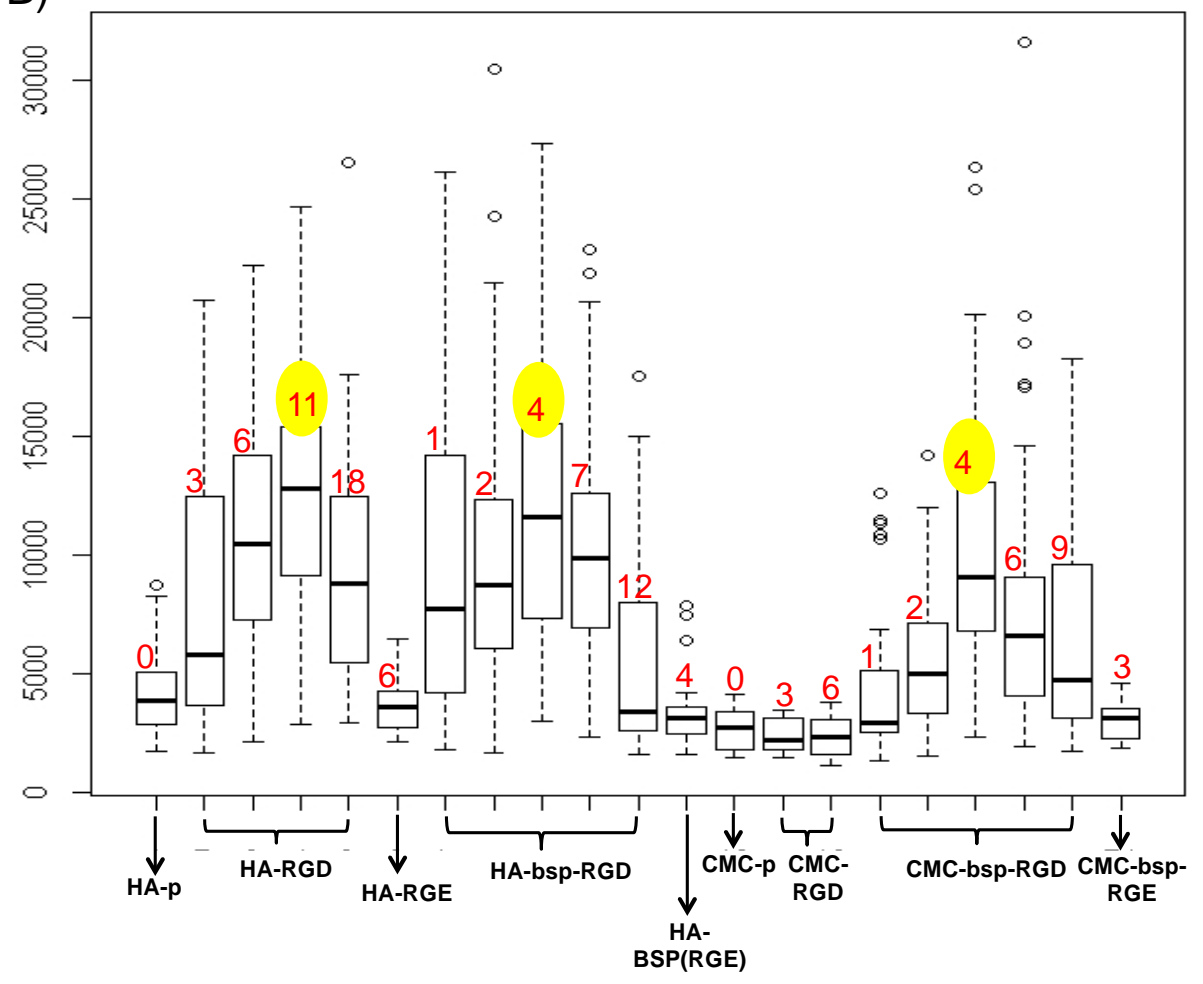

Figure 2 


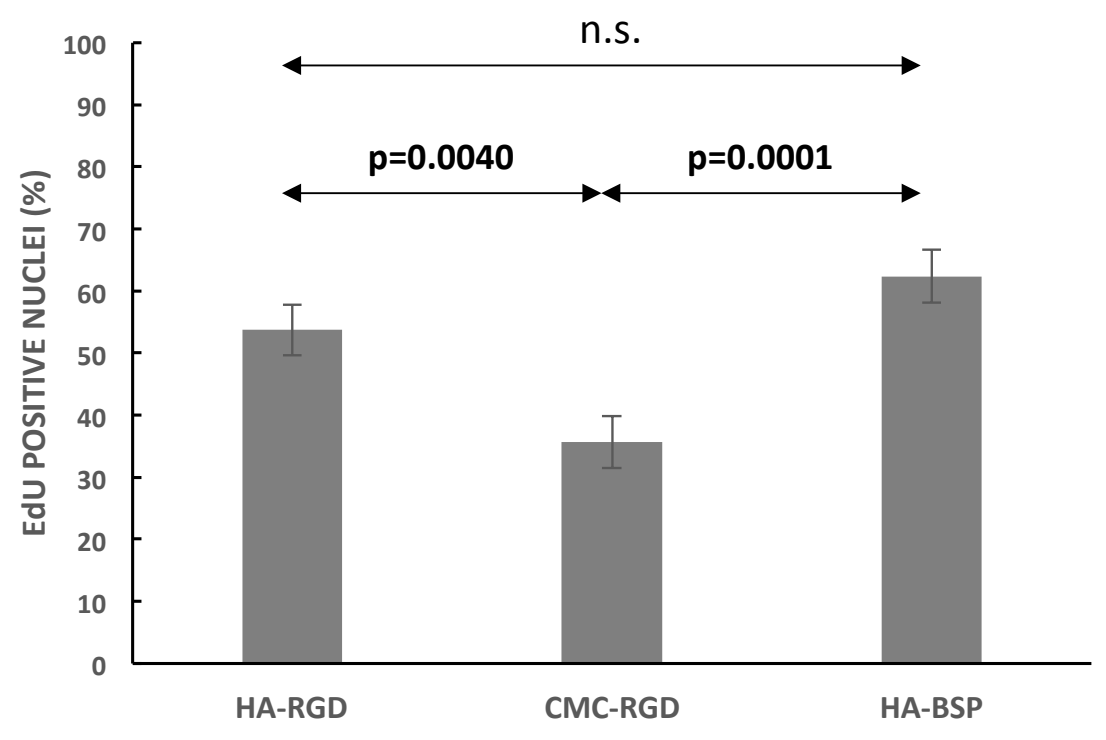

2

3

4

5

6

7

Figure 3

8 


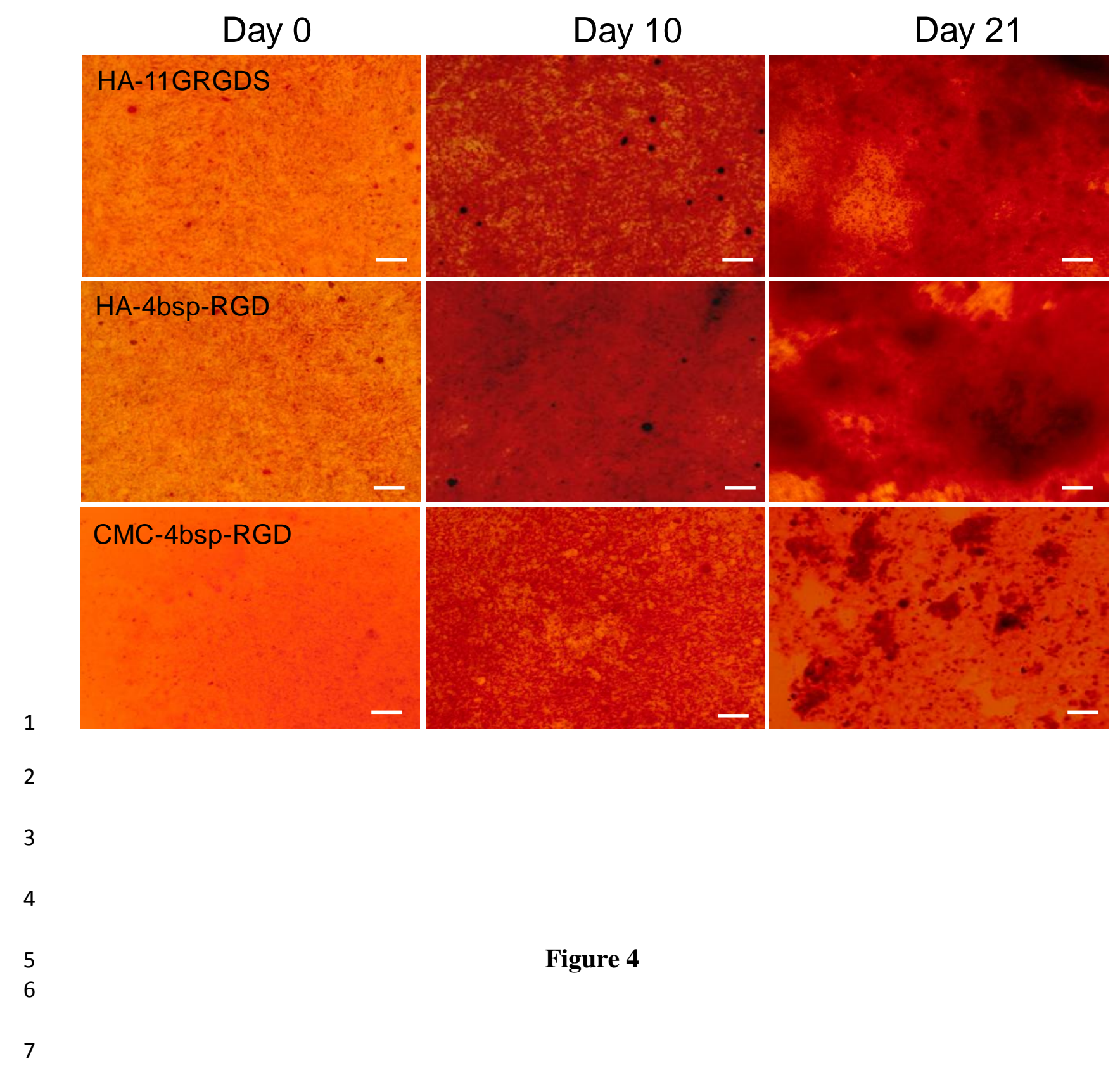




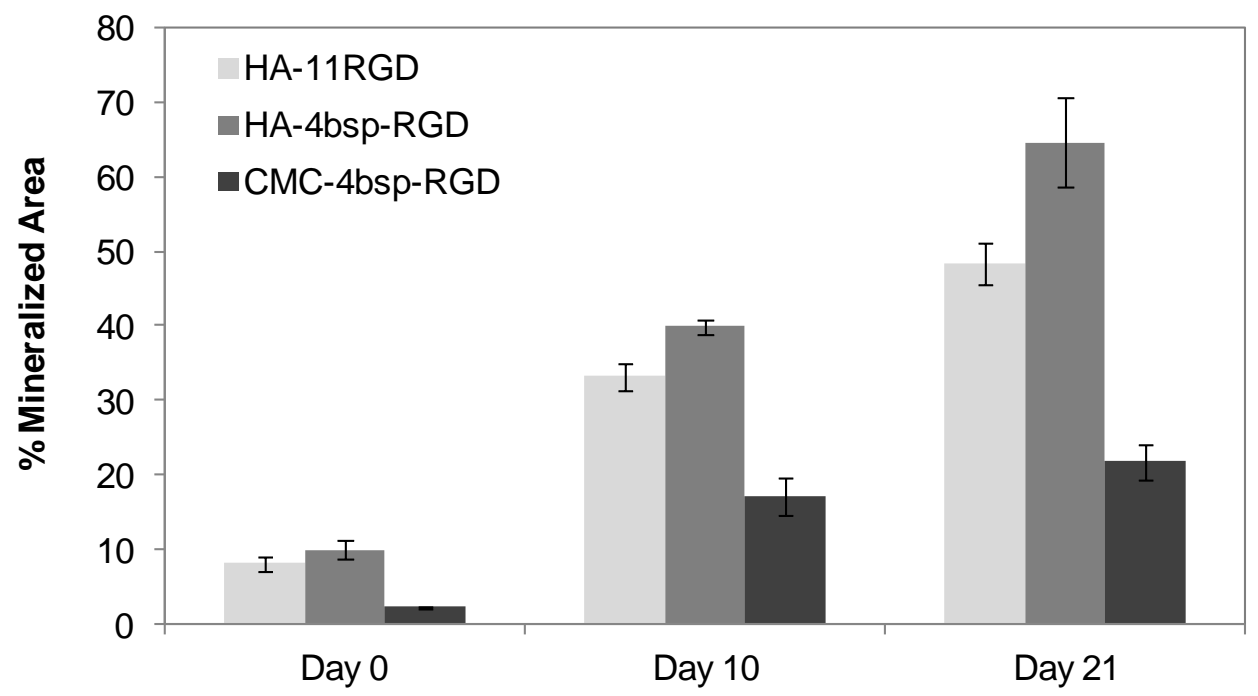

2

3

4

5

Figure 5

6

7 
2

3
4

5

6

7

8

9

10

11

12

13

14

15

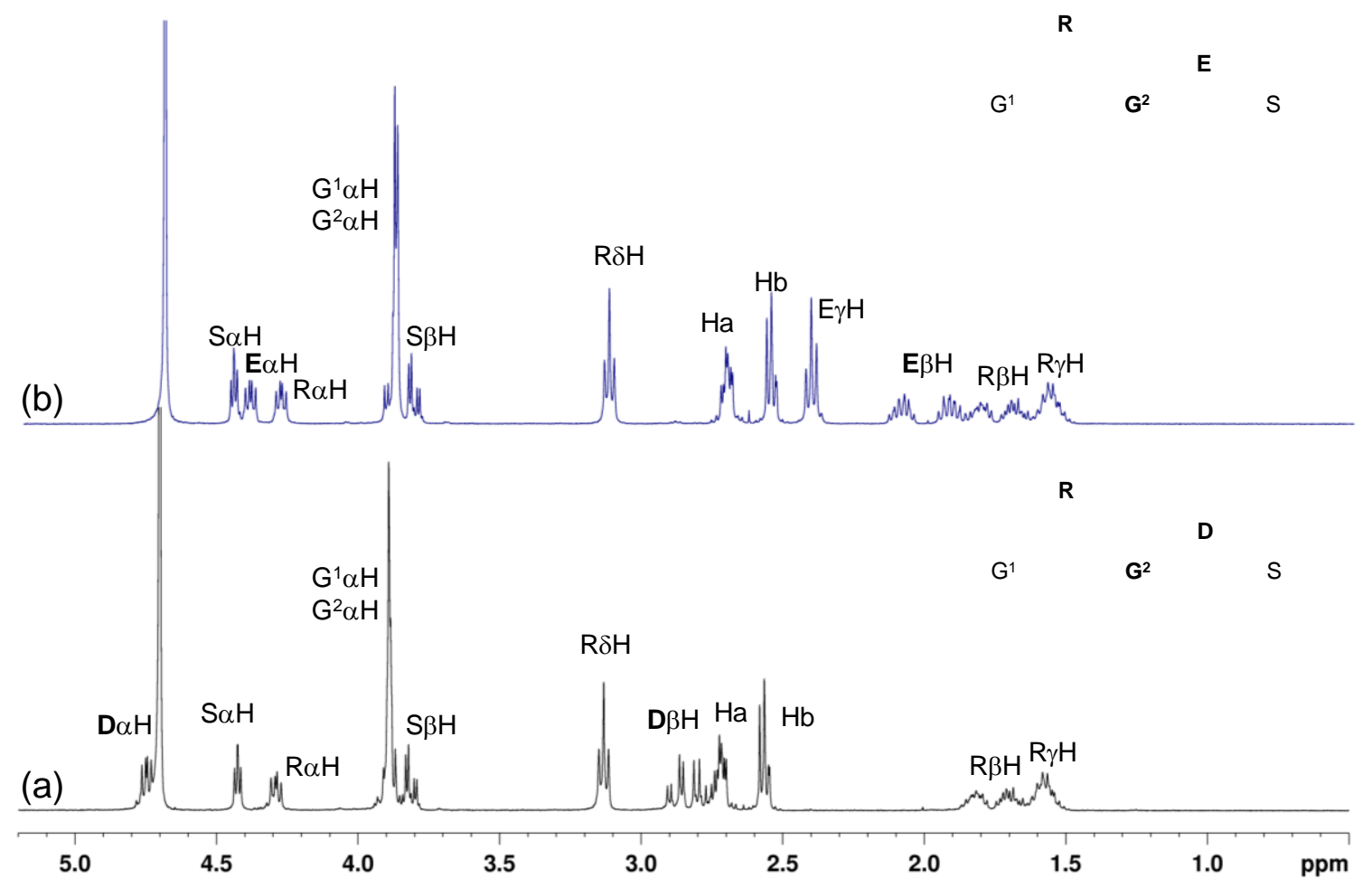

Figure S1. ${ }^{1} \mathrm{H}$ NMR spectra (400 MHz, $3 \mathrm{mg} / \mathrm{mL}$ in $\mathrm{D}_{2} \mathrm{O}, 25^{\circ} \mathrm{C}$ ) of GRGDS (a) and GRGDE (b). 


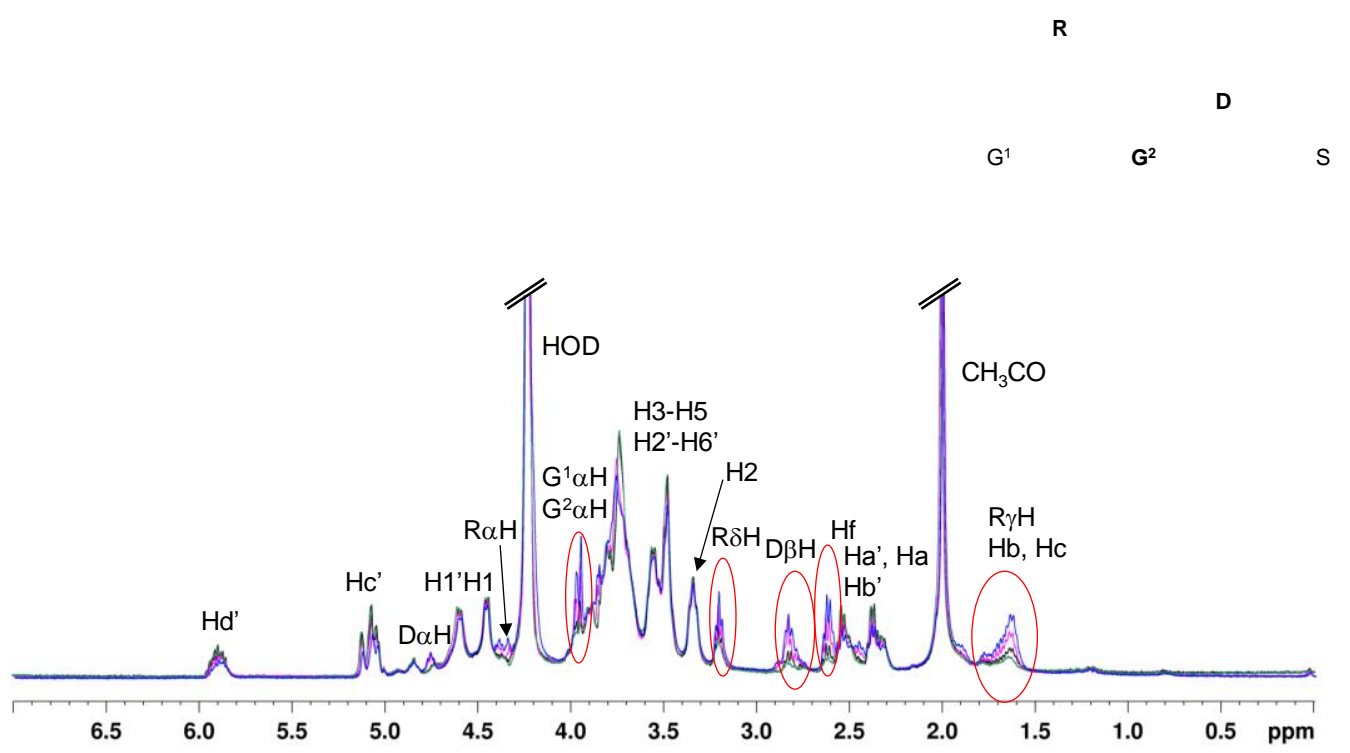

2

3 Figure S2. ${ }^{1} \mathrm{H}$ NMR spectra (400 MHz, $6 \mathrm{mg} / \mathrm{mL}$ in $\mathrm{D}_{2} \mathrm{O}, 80{ }^{\circ} \mathrm{C}$ ) of HA-18RGD (blue curve), HA-11RGD (pink curve), HA-6RGD (black curve) and HA-3RGD (green curve).

5

6

7

8 
$\mathrm{R}^{1}$

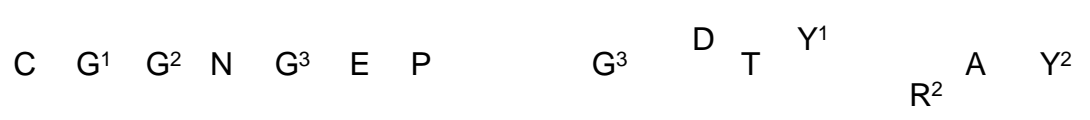

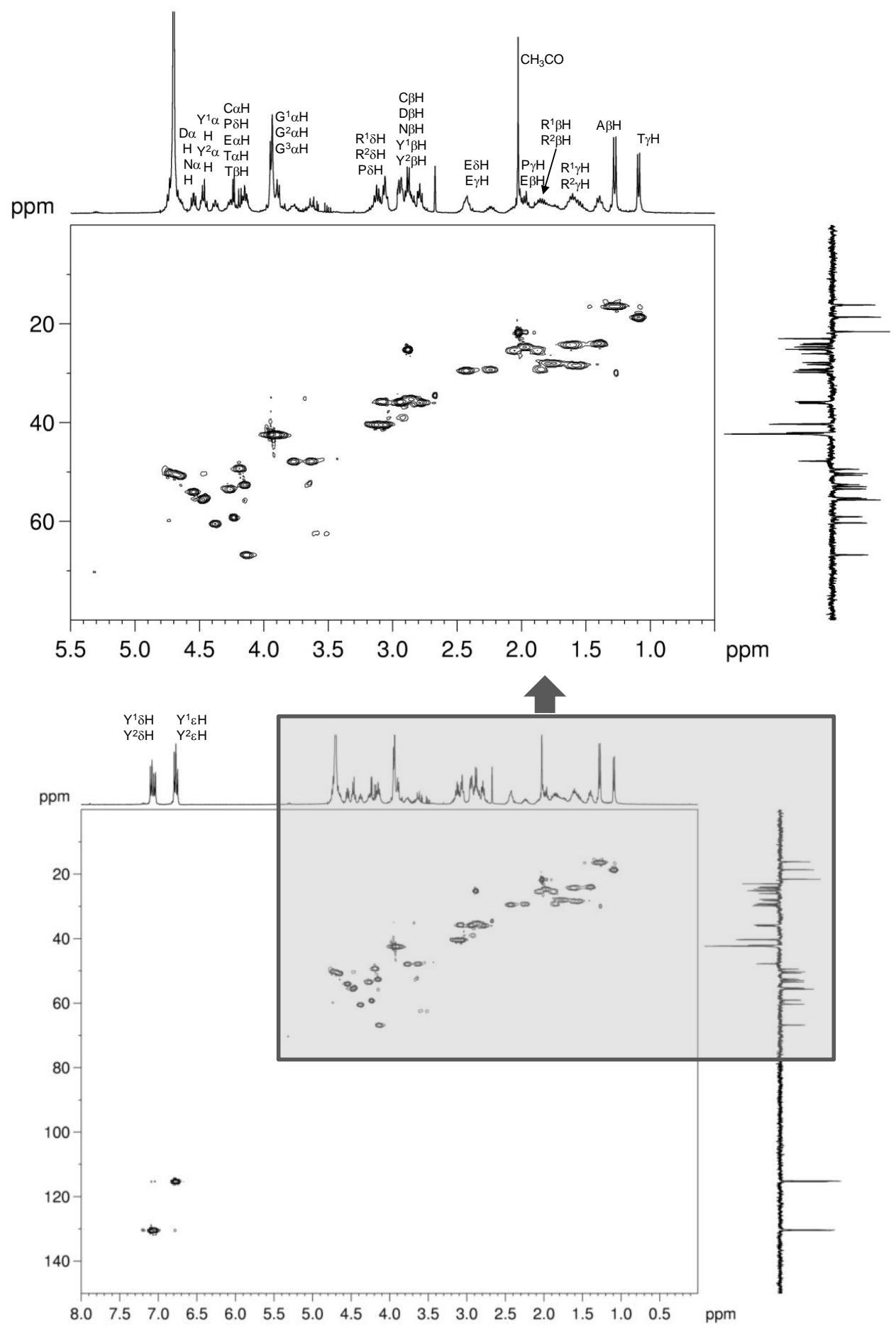


1 Figure S3.Complete and partial contour plots of a ${ }^{1} \mathrm{H},{ }^{13} \mathrm{C}-\mathrm{HSQC}$ experiment performed on bsp2 RGD $\left(4 \mathrm{mg} / \mathrm{mL}\right.$ in $\left.\mathrm{D}_{2} \mathrm{O}, 25{ }^{\circ} \mathrm{C}\right)$. The ${ }^{1} \mathrm{H}$ and ${ }^{13} \mathrm{C}$ DEPT135 NMRprojection spectra of the peptide are shown along the horizontal and vertical axes, respectively.
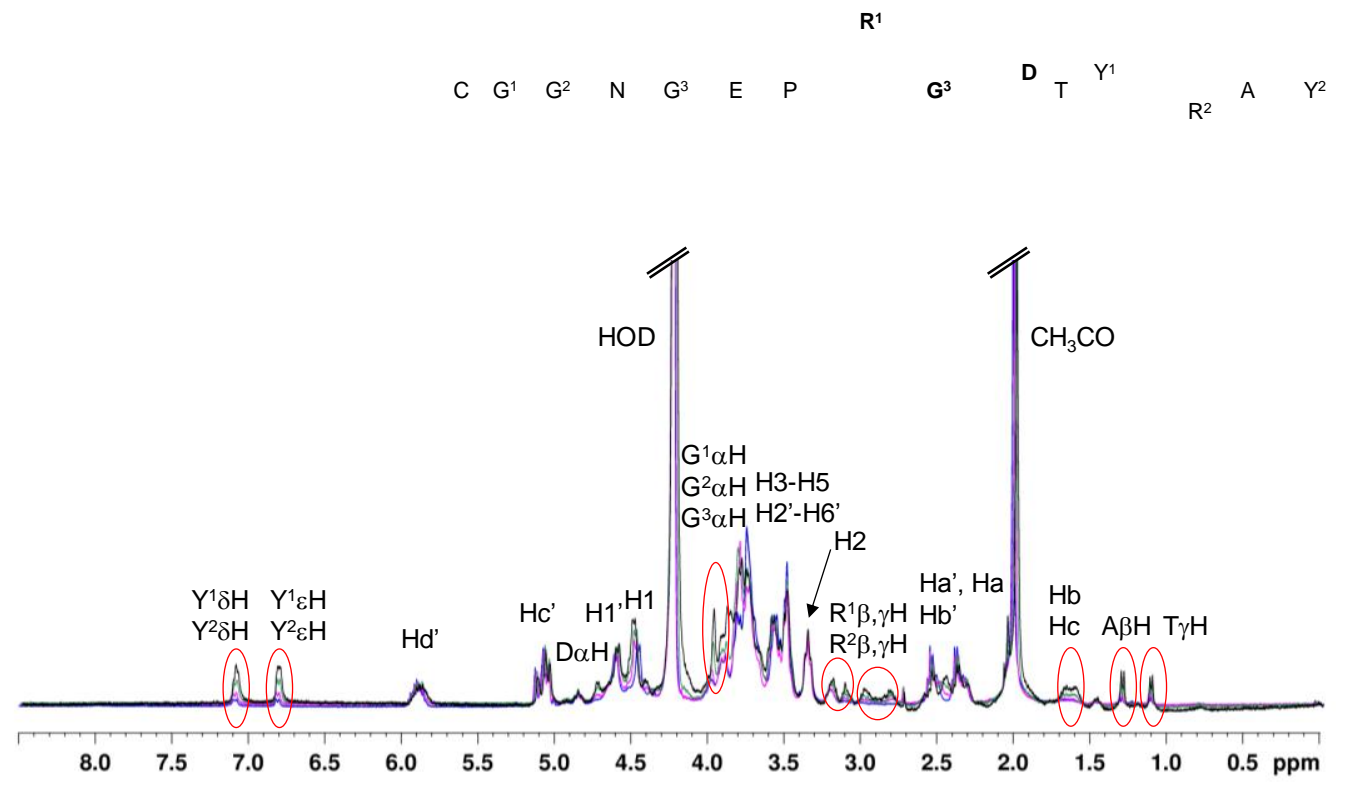

5

6 Figure S4. ${ }^{1} \mathrm{H}$ NMR spectra (400 MHz, $6 \mathrm{mg} / \mathrm{mL}$ in $\mathrm{D}_{2} \mathrm{O}, 80{ }^{\circ} \mathrm{C}$ ) of HA-12bsp-RGD (black

7 curve), HA-7bsp-RGD (green curve), HA-4bsp-RGD (pink curve) and HA-2bsp-RGD (blue 8 curve). 


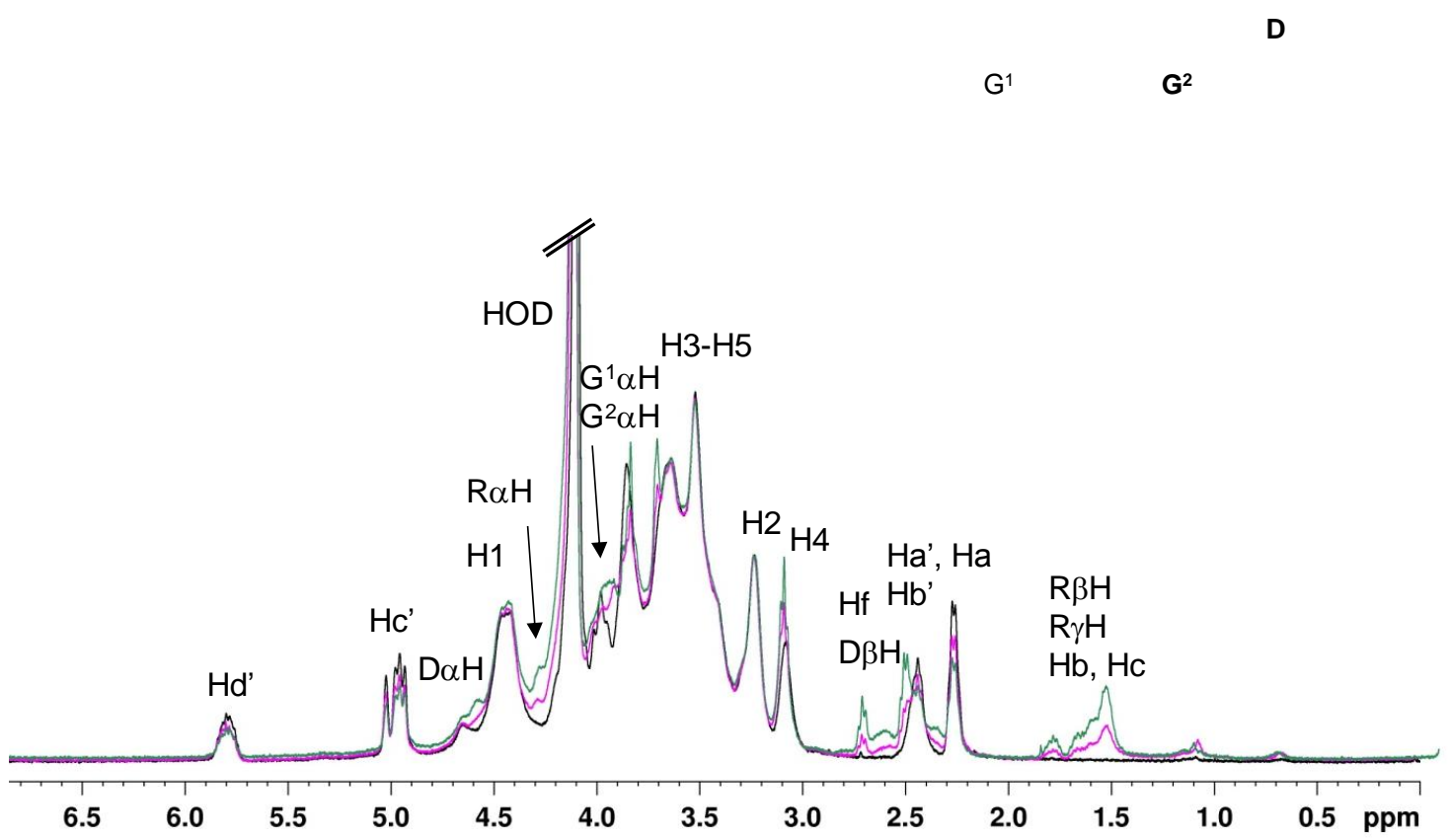

$3 \quad$ Figure S5. ${ }^{1} \mathrm{H}$ NMR spectra $\left(400 \mathrm{MHz}, 6 \mathrm{mg} / \mathrm{mL}\right.$ in $\left.\mathrm{D}_{2} \mathrm{O}, 80{ }^{\circ} \mathrm{C}\right)$ of pentenoate-modified CMC (black curve), CMC-6RGD (green curve) and CMC-3RGD (pink curve). 
$\mathbf{R}^{1}$
$\begin{array}{llllllllll}C & G^{1} & G^{2} & N & G^{3} & E & P\end{array}$
$\mathbf{G}^{3}$
D $_{T} \mathrm{Y}^{1}$
$R^{2} \quad \mathrm{~A} \quad \mathrm{Y}^{2}$

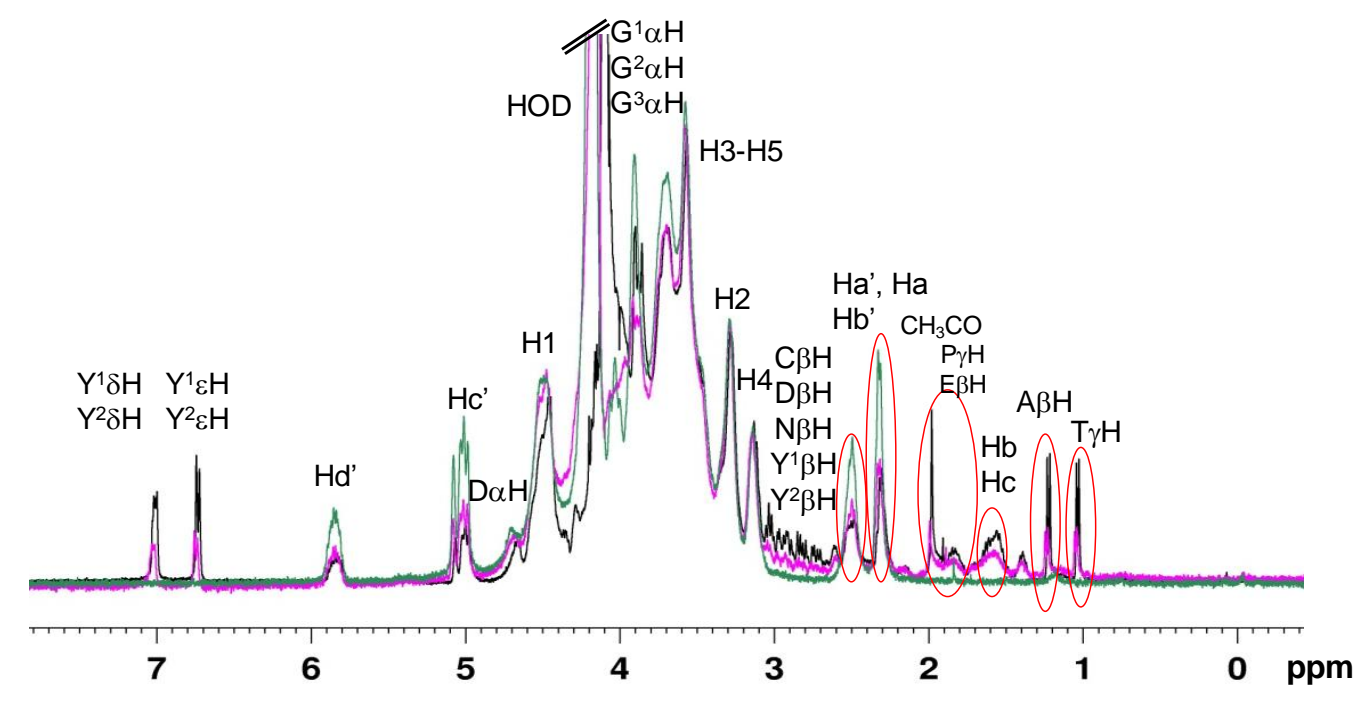

$4 \quad$ Figure S5. ${ }^{1} \mathrm{H}$ NMR spectra $\left(400 \mathrm{MHz}, 6 \mathrm{mg} / \mathrm{mL}\right.$ in $\left.\mathrm{D}_{2} \mathrm{O}, 80{ }^{\circ} \mathrm{C}\right)$ of pentenoate-modified CMC 5 (green curve), CMC-9bsp-RGD (black curve) and CMC-4bsp-RGD (pink curve). 
8 Figure S6. ${ }^{1} \mathrm{H}$ NMR spectra (400 MHz, $6 \mathrm{mg} / \mathrm{mL}$ in $\mathrm{D}_{2} \mathrm{O}, 80{ }^{\circ} \mathrm{C}$ ) of HA-12bsp-RGD (black 9 curve), HA-7bsp-RGD (green curve), HA-4bsp-RGD (pink curve) and HA-2bsp-RGD (blue 10 curve).

11

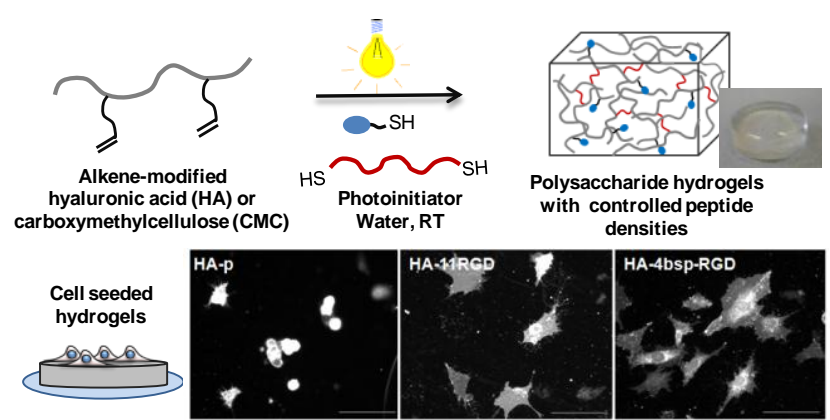

